\title{
Surface soil quality in five midwestern cropland Conservation Effects Assessment Project watersheds
}

\author{
D.L. Karlen, D.E. Stott, C.A. Cambardella, R.J. Kremer, K.W. King, and G.W. McCarty
}

\begin{abstract}
Soil quality (SQ) assessment is a proactive process for evaluating soil and crop management effects on biological, chemical, and physical indicators of soil health. Our objectives were to evaluate several SQ indicators within five Agricultural Research Service (ARS) experimental watersheds (WS) and determine if those indicators were affected by manure, tillage, or crop rotation histories. Ten soil quality indicators were measured within each of 6000 to $5 \mathrm{~cm}$ (0 to 2 in) depth and 3985 to $15 \mathrm{~cm}$ (2 to 6 in) depth increment samples, evaluated statistically, and then scored using the Soil Management Assessment Framework. Except for soil organic carbon (C) at both depth increments or microbial biomass $\mathrm{C}$ and $\beta$-glucosidase within the 5 to $15 \mathrm{~cm}$ increment, the indicators showed significant WS differences. Except for surface soil-test phosphorous (P), Soil Management Assessment Framework indicator scores and overall soil quality index values also showed significant $(p \leq 0.05)$ WS differences. Microbial biomass $\mathrm{C}$ was significantly affected by crop rotation at both sampling depths and by WS within the surface $5 \mathrm{~cm}$. $\beta$-glucosidase was significantly affected by all four factors (WS, manure, tillage, and crop rotation) and their interactions within the 0 to $5 \mathrm{~cm}$ increment. The water-stable macroaggregate indictor within the 0 to $5 \mathrm{~cm}$ increment and within the 5 to $15 \mathrm{~cm}$ increment, however, were not significantly different for the tillage and manure application treatments, respectively. Our study showed that the ARS Conservation Effects Assessment Project (CEAP) watersheds provided a moderately controlled example that watershed-scale monitoring of soil quality is feasible and should be used to monitor soil health and/or conservation program effectiveness.
\end{abstract}

Key words: Conservation Effects Assessment Project-crop rotation-manure-soil health-Soil Management Assessment Framework-tillage

\begin{abstract}
The USDA Agricultural Research Service (ARS) Cropland Conservation Effects Assessment Project (CEAP) was initiated in 2003 to scientifically evaluate the effectiveness of Natural Resources Conservation Service (NRCS) conservation practices because of their increasing public cost (Karlen 2008; Richardson et al. 2008). Soil quality (SQ) assessments were incorporated into the ARS Cropland CEAP in 2006 based on a National Research Council (NRC 1993) recommendation that soil quality and water quality impacts be quantified when evaluating effectiveness of NRCS conservation programs.
\end{abstract}

This SQ assessment at ARS cropland CEAP sites followed more than a decade of SQ research (Karlen et al. 2008a) that was the sustainability of many soil and crop management decisions (Pesek 1994).

In response to those questions, the NRCS adopted the soil conditioning index (SCI) as one factor for determining eligibility for the USDA Conservation Security Program and the Environmental Quality Incentives Program funds following passage of the 2002 Farm Bill. Their justification was that if only one indicator could be used to evaluate SQ, soil organic matter would be the best choice because of the multitude of soil physical, chemical, and biological properties and processes it influences (USDA NRCS 2003). However, comparisons between the SCI and Soil Management Assessment Framework (SMAF) indices for semiarid soils indicated the SCI was not well correlated with total soil carbon (C) (Zobeck et al. 2008).

We used the SMAF, as described by Andrews et al. (2004), to assess SQ effects within five cropland CEAP watersheds. The SMAF provides a framework for evaluating biological, chemical, and physical indicators of SQ (soil health) and, if desired, combining the ratings into an overall assessment of dynamic soil quality (Andrews et al. 2002a, 2002b, 2004). The SMAF emphasizes a dynamic view of soil quality which involves detecting soil response to current or recent management decisions in contrast to inherent soil quality which is determined by basic soil forming factors and is relatively unresponsive to recent soil and crop management practices. Soil Management Assessment Framework scoring curves or interpretation algorithms have been developed for 13 indicators including the quantity of water-stable macroaggregate (WSA), plant-available water

inspired by Alexander (1971) and Warkentin and Fletcher (1977) who stated that multifactor assessment protocols were needed to assess soil health/quality (Karlen et al. 2003) Initiation of SQ research also coincided with an increased emphasis on sustainable agriculture during the mid- to late 1980s (NRC 1989) that brought public attention to the increasing degradation of soil resources and the implication of those changes for environmental health. These efforts were not limited to the United States as evidenced by the Canadian Soil Quality Evaluation Program, one of the first national efforts focused specifically on SQ assessment (CCME 1999). As discussion and general interest in SQ and soil health spread worldwide (Karlen et al. 1997, 2001), questions began to be raised regarding
Douglas $L$. Karlen is a research soil scientist with the USDA Agricultural Research Service (ARS) National Laboratory for Agriculture and Stott is a research soil scientist with the USDA ARS National Soil Erosion Research Laboratory in West Lafayette, Indiana. Cynthia A. Cambardella is an ecologist with the USDA ARS NLAE in Ames, lowa. Robert J. Kremer is a research soil scientist with the USDA ARS Cropping Systems and Water Quality Research Unit at the University of Missouri in Columbia, Missouri. Kevin W. King is an agricultural engineer with the USDA ARS Soil Drainage Research Unit at The Ohio State University in Columbus, Ohio. Greg W. McCarty is a research soil scientist with the USDA ARS Hydrology and Remote Sensing Laboratory in Beltsville, Maryland. the Environment (NLAE) in Ames, lowa. Diane E. 
holding capacity, water-filled pore space, bulk density (BD), electrical conductivity (EC), $\mathrm{pH}$, sodium adsorption ratio, Mehlich III extractable (soil-test) phosphorus (P) and potassium (K), soil organic carbon (SOC), microbial biomass carbon (MBC), potentially mineralizable nitrogen (PMN), and $\beta$-glucosidase (BG) activity (Andrews et al. 2004; Wienhold et al. 2009; Stott et al. 2010). However, as few as five SQ indicators can be used to provide useful soil and crop management assessments (Karlen et al. 2008a) provided biological, chemical, and physical properties and processes affecting soil health are represented in the analysis.

General characteristics of the five cropland CEAP watersheds for which this SQ assessment was conducted are summarized in table 1. Other features of each experimental watershed (WS) follow:

1. The South Fork (SF) of the Iowa River in north-central Iowa, represents relatively young landscapes, developed in glacial till with poorly dissected and internally drained prairie potholes and hydric soils occupying $54 \%$ of the WS area. The SF WS has several swine confinement facilities which provide manure as a component of many nutrient management plans and has numerous subsurface tile drains and ditches, some that were first installed more than 100 years ago. This extensive drainage network not only helps increase crop production, but also accelerates transport of excess soil water with dissolved contaminants that can lead to impaired water quality.

2. The Walnut Creek (WC) WS near Ames in central Iowa, represents a smaller intensive agricultural landscape, also developed in glacial till on the Des Moines Lobe with a gently rolling and poorly drained topography. About 60\% of the area is tile drained, but there are few animal operations in this WS.

3. The Cedar Creek (CC) WS is located within the St. Joseph River watershed in northeastern Indiana. The landscape is dominated by closed depressions that require extensive surface drainage for successful corn (Zea mays L.) and soybean (Glycine max L.) production.

4. The Mark Twain (MT) WS is part of the Salt River basin located in northeastern Missouri. The basin has flat to gently rolling topography with soils that generally possess a shallow claypan which restricts vertical movement of water, and thus increases surface runoff and subsurface lateral water flow. There is very little tile drainage in this WS.

5. The Upper Big Walnut Creek (UBWC) WS located in central Ohio, was selected because the area is also extensively tile drained, and this WS drains into a reservoir that provides domestic water for Columbus and surrounding communities. Our objectives for this study were to (1) evaluate several SQ indicators within five ARS experimental watersheds and (2) determine if those indicators were affected by location, manure application within the past year, tillage practice or crop rotation.

\section{Methods and Materials}

Sampling Protocol. The five WS were sampled following grain harvest in 2006 (SF and WC), 2007 (CC), and 2008 (MT and UBWC). A total of 600 soil samples from 0 to $5 \mathrm{~cm}$ (0 to $2 \mathrm{in})$ and another 398 samples from 5 to $15 \mathrm{~cm}$ (2 to 6 in) were collected from multiple locations within each WS. The spatial sampling design within each WS was different as illustrated by Stott et al. (2011, 2013) because the specific SQ assessment questions being asked were different. For example, there were no samples for the 5 to $15 \mathrm{~cm}$ (2 to 6 in) depth within the SF WS. The only requirement for all cropland CEAP WS was that at least half of the samples were to be taken from the 0 to $5 \mathrm{~cm}$ (0 to 2 in) depth increment because fiscal resources used to support this multilocation endeavor originated within the ARS Global Climate Change National Program. Therefore, in addition to meeting the CEAP SQ assessment goals, this study also provided data for use in ARS global climate change modeling and assessment projects.

Available human and fiscal resources thus limited the total number of samples that could be processed for each watershed to an average of 250. Therefore, local research teams had to decide whether collecting samples from only the 0 to $5 \mathrm{~cm}$ ( 0 to 2 in) depth would be more or less informative for the questions they were asking than having half as many sampling sites, but two depth increments.

Metadata from each WS was used to identify sites that were representative of (1) areas receiving manure $(\mathrm{M})$ on an annual or biannual basis; (2) conventional or reduced tillage versus no-tillage (T); and (3) one of five general crop rotations ([CR] i.e., continuous corn, corn-soybean, corn-soybean-wheat [Triticum aestivum L.], soybean-soybean-other crop or forage-based). The cross-location SQ indicator assessment project was superimposed on the combined dataset, which was compiled using data collected to help answer each set of WS specific questions. Although, the inconsistency in sampling strategies among the five WS pose some statistical challenges, we are confident this multilocation study will provide useful information regarding how various SQ indicators are affected by soil and crop management practices.

At each sampling site, 20 soil cores (3.2 $\mathrm{cm}$ [1.25 in] diameter) were collected within a $3 \mathrm{~m}$ (10 ft) radius of a global positioning system (GPS)-specified sampling point from the 0 to $5 \mathrm{~cm}$ (0 to $2 \mathrm{in})$ depth. Also, except for the SF WS, samples were taken from the 5 to $15 \mathrm{~cm}$ (2 to 6 in) depth. Surface residues were cleared from each sampling point so that collection began at the mineral soil surface. All soil from each sampling site and depth increment was placed in plastic bag that was sealed and transported back to the laboratory before weighing, mixing, and taking a $100 \mathrm{~g}(3.5 \mathrm{oz})$ subsample that was dried at $105^{\circ} \mathrm{C}\left(221^{\circ} \mathrm{F}\right)$ to determine soil water content. The total field-moist weight per composite sample was adjusted to a dry weight and divided by the volume associated with the 20 soil cores to estimate BD (Grossman and Reinsch 2002). Each sample was passed through an $8 \mathrm{~mm}$ (0.35 in) sieve to remove rocks and plant material larger than the mesh openings. The weight of removed material was recorded. A representative 150 g $(5.3 \mathrm{oz})$ subsample was removed, placed in a plastic bag, and stored at $4^{\circ} \mathrm{C}\left(39.2^{\circ} \mathrm{F}\right)$ for soil $\mathrm{MBC}$ determination. Another representative portion was hand sieved to pass a $2 \mathrm{~mm}$ (0.07 in) sieve, air-dried, and stored at $4^{\circ} \mathrm{C}\left(39.2^{\circ} \mathrm{F}\right)$ until used for determining PMN. The remainder of the sample was airdried, ground to pass a $2 \mathrm{~mm}$ sieve, bagged, and stored at $4^{\circ} \mathrm{C}\left(39.2^{\circ} \mathrm{F}\right)$.

Soil Assays. The quantity of WSA was determined using a modified Yoder sieving machine set to 30 strokes per minute for 5 minutes (Kemper and Roseneau 1986). Twenty-five grams of $8 \mathrm{~mm}$ (0.35 in) sieved, air-dried soil was placed on top of a nest of four sieves with openings of 2, 1, 0.5, and $0.25 \mathrm{~mm}(0.35,0.04,0.02$, and $0.01 \mathrm{in})$ (sieve numbers $10,18,35,60$, respectively), and physical disruption of the aggregates was carried out in deionized water to limit 
Table 1

General characteristics of five midwestern United States cropland Conservation Effects Assessment Project watersheds where soil quality indicator comparisons were made.

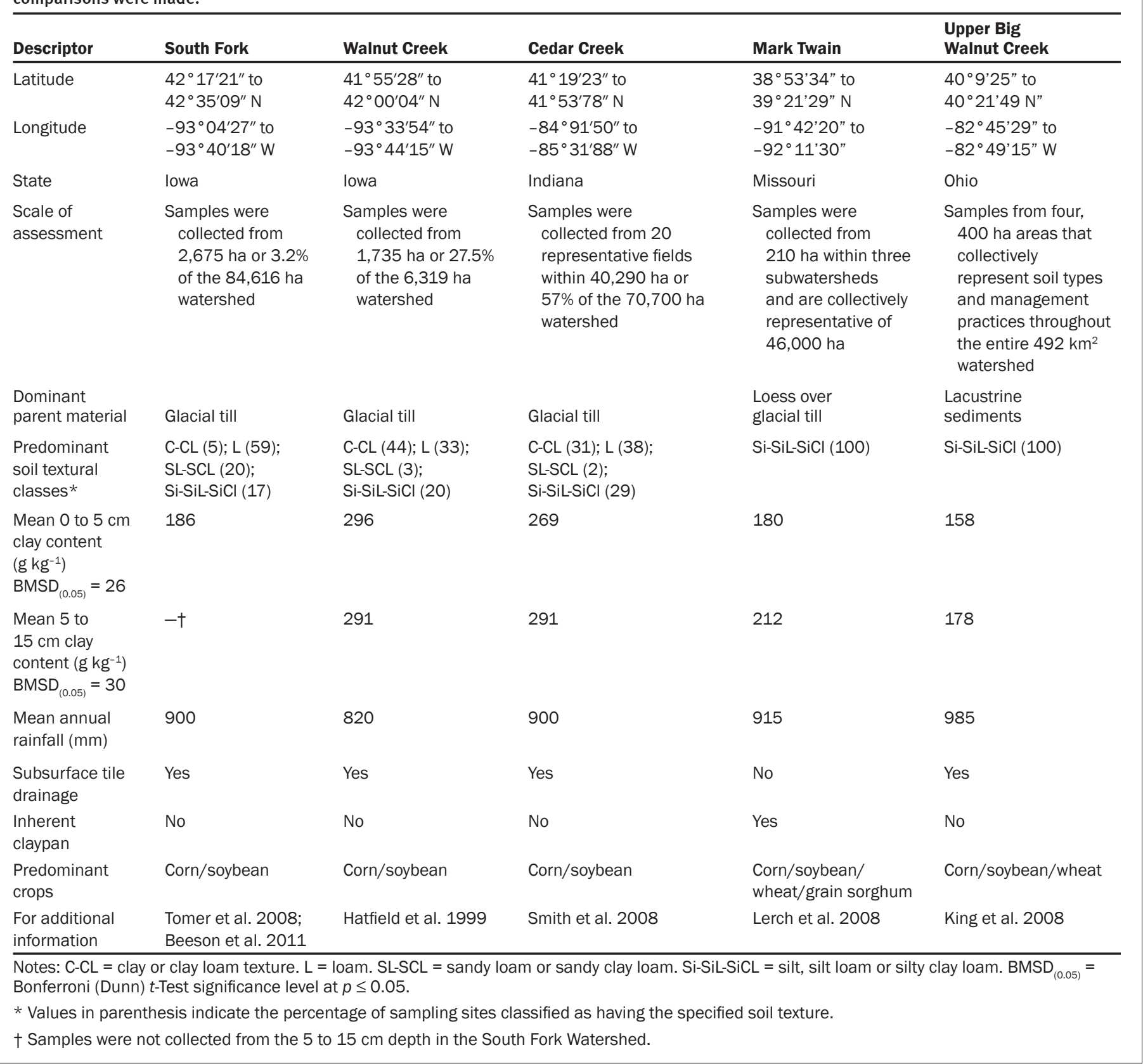

chemical dispersion of the aggregates. Soil texture was determined using the hydrometer procedure of Gee and Or (2002) with readings corrected for temperature. Percent silt was calculated as the difference of 100 minus the percentage of sand minus the percentage of clay (i.e., $100-$ [\% sand $+\%$ clay $]$ ).

Electrical conductivity (Whitney 1998) and $\mathrm{pH}$ (Watson and Brown 1998) were determined with standard meters using $20 \mathrm{~g}(0.7 \mathrm{oz})$ of air dried $2 \mathrm{~mm}$ (0.35 in) sieved soil mixed in a 1:1 soil-to-water ratio.
Mehlich III extractable (Mehlich 1984) P and $\mathrm{K}$ concentrations were determined using an inductively coupled plasma-atomic emission spectrograph (ICP-OES) (Optima 5300 DV ${ }^{1}$, Perkin-Elmer, Shelton, Connecticut).

Total soil $\mathrm{C}$ was measured by dry combustion (EA1112 Flash NC Elemental analyzer, Thermo Finnegan Scientific Inc., Waltham, Massachusetts) using air-dried, ground soil. For samples with a $\mathrm{pH}$ of 7.3 or greater, soil inorganic $\mathrm{C}$ was quantified according to the method of Sherrod et al. (2002). Soil organic
C was calculated as the difference between total and inorganic C. Microbial biomass C was determined using $8 \mathrm{~mm}$ (0.35 in) sieved field-moist samples with standard soil fumigation and chemical extractions (Brookes et al. 1985; Vance et al. 1987). Potentially mineralizable $\mathrm{N}$ was measured using an aerobic 28-day incubation method described by Drinkwater et al. (1996) with mineral $\mathrm{N}\left[\left(\mathrm{NO}_{2}+\mathrm{NO}_{3}\right)\right.$ $+\mathrm{NH}_{4}$ ] determined colorimetrically using a flow injection system (Lachat Instruments, Milwaukee, Wisconsin). $\beta$-glucosidase activity 
was determined using the method of Eivazi and Tabatabai (1988) and expressed as mg p-nitrophenol (pnp) released per kilogram of soil per hour of incubation.

Soil Management Assessment Framework. Ten SQ indicators (BD, WSA, pH, EC, soil-test $\mathrm{P}$ and $\mathrm{K}, \mathrm{SOC}, \mathrm{MBC}, \mathrm{PMN}$, and BG activity) were used to calculate a soil quality index using the SMAF. Each measured indicator was scored using an Excel spreadsheet that is available from the corresponding author. The spreadsheet contains scoring curves that were developed for each potential indicator based on soil taxonomy, texture, typical temperature and rainfall regimes for the sampling area, mineralogy, slope, season samples were collected, dominant crop, and selected methods of $\mathrm{P}$ and $\mathrm{EC}$ analysis as previously published (Andrews et al. 2004; Wienhold et al. 2009; Stott et al. 2010). After obtaining individual indicator scores, a combined SQI was calculated by summing the scores, multiplying by 100 , and dividing by the number of measurements for each assessment. The overall SQI was also subdivided into physical (BD + WSA), chemical ( $\mathrm{pH}$ and EC), biological (SOC, MBC, PMN, and BG activity) and nutrient indices (soil-test $\mathrm{P}$ and $\mathrm{K}$ ) using subsets of the scored indicator data. This approach identifies the management areas of greatest concern (i.e., lowest index scores) so that land managers can be given better guidance on how to most efficiently restore or improve soil health at that specific location (Stott et al. 2010).

Statistical Analysis. Indicator measurements, SMAF scores, and overall SQI values were analyzed using SAS version 9.2 (SAS Institute, Cary, North Carolina). An analysis of variance (ANOVA) was computed using PROC GLM to determine if there were significant differences due to WS location, manure (M) application history, tillage (T) practice, or crop rotation (CR). The data were also analyzed to determine if there were significant WS-M, WS-T, or WS-CR interactions. Finally, if the ANOVA f-test was significant, a Bonferroni Minimum Significant Difference (MSD) at $p$ $=0.05$ was computed for mean separation.

\section{Results and Discussion}

Watershed Characteristics. Among the five cropland CEAP watersheds, clay content (table 1) was lowest in samples collected from both depths within the UBWC WS in Ohio. The highest levels were found in samples from
WC in Iowa and CC in Indiana, where more samples had clay, clay loam, or loam textures. Samples from the MT WS, which is located in the claypan region of Missouri, had an intermediate clay content at both depths, although the 0 to $5 \mathrm{~cm}$ ( 0 to 2 in) samples were similar to those within the SF WS. With regard to SQ assessment, clay content as well as factors such as profile depth, slope, parent material, and mean annual rainfall are considered to be indicators of inherent SQ (Karlen et al. 2001, 2008a). Those factors are captured in traditional soil capability ratings but also influence dynamic or temporal soil quality indicator ranges, and are thus reflected in the scoring curves (Andrews et al. 2004; Wienhold et al. 2009) developed for interpreting SQ indicator measurements.

Indicator Differences Among Watersheds. The overall ANOVA results (table 2) show that, except for SOC at both sampling depths, or $\mathrm{MBC}$ and $\mathrm{BG}$ within the 5 to $15 \mathrm{~cm} \mathrm{(2}$ to 6 in) increment, all measured SQ indicators showed significant WS differences. This was not a surprise since the CEAP WS were selected to represent a variety of landscapes with different soils, cropping systems, and animal operation intensities (i.e., availability of animal manure) as shown in table 1 . The lack of significant differences in SOC is also consistent with many other soil C studies (Johnson et al. 2014) presumably because of the variation in SOC encountered in many midwestern United States soils. This hypothesis appears to be confirmed by mean SOC data presented in table 3 . Even though an $11 \mathrm{~g}$ $\mathrm{kg}^{-1}(1.1 \%)$ difference in SOC was measured in surface within the 0 to $5 \mathrm{~cm}$ (0 to 2 in) samples and a $13 \mathrm{~g} \mathrm{~kg}^{-1}$ (1.3\%) difference was measured among the watersheds within the 5 to $15 \mathrm{~cm}$ (2 to 6 in) depth increment, WS differences were not statistically significant at $p \leq 0.05$. Similar SOC differences (i.e., 9 to 11 $\mathrm{g} \mathrm{kg}^{-1}$ ) were noted among the five CR, but again those differences were not significant.

The SMAF, which normalizes indicator data using scoring curves (Andrews et al. 2004), helps overcome the spatial variation illustrated above. For example, the overall ANOVA for SMAF scores (table 4) show that except for surface soil-test $\mathrm{P}$, all indicator scores and overall SQI values for both sampling depths within the five watersheds were significantly different at $(p \leq 0.05)$. Furthermore, SOC scored values for the CR showed statistically significant differences. Both the WS and CR responses can be seen in table 5, which shows that scored values for the five WS ranged from 0.61 to 0.97 while among the five CR they ranged from 0.65 to 0.86 .

Among the 10 soil quality indicators, BG had the lowest scores at both depth increments (table 5). The scoring curve for this indicator was developed with long-term no-till or pasture data from similar soils to set the upper end of the curve (Stott et al. 2010) and from long-term conventionally tilled (moldboard plow) systems to define the lower end. Low scores indicate that less of this vital enzyme, which is involved in cellulose degradation, is being produced, but at this time we lack knowledge as to when these levels fall below a threshold where residue and root decomposition would be impeded enough to impact critical soil functions.

Bulk density in the surface increment was highest in samples from WC and MT WS (table 3), presumably reflecting higher clay content at WC and clay-pan morphology within the MT WS. For BD, SOC, MBC, and $\mathrm{BG}$, the 5 to $15 \mathrm{~cm}$ (2 to 6 in) samples had substantially lower scores (table 4 ) than for the 0 to $5 \mathrm{~cm}$ ( 0 to 2 in) increment. Presumably, the latter three indicators reflect long-term SOC loss when compared to inherent or potential levels reflected in the SMAF scoring curves (Andrews et al. 2004). Similarly, lower BD scores reflect the higher measured values which suggest that subsurface compaction may be an emerging soil health concern.

Mehlich III extractable $\mathrm{P}$ and $\mathrm{K}$ values (table 3 ) and scores (table 5) were lower in the 5 to $15 \mathrm{~cm}$ (2 to 6 in) samples than in the 0 to $5 \mathrm{~cm}$ ( 0 to $2 \mathrm{in}$ ) increment within the four watersheds where both depths were evaluated. Measured and scored values for the remaining four indicators (WSA, PMN, $\mathrm{pH}$, and EC) also showed significant WS differences, but none of them would be considered limiting for crop production.

The overall SQI values within the 0 to 5 $\mathrm{cm}$ (0 to 2 in) depth indicated soils within all five WS were functioning at between 78\% and $92 \%$ of their potential which is consistent with other midwestern SQ assessment studies (Karlen et al. 2006, 2008a, 2008b). Similarly, soils from the 5 to $15 \mathrm{~cm}$ (2 to 6 in) depth increment within the four sampled WS were functioning at between $63 \%$ and $80 \%$ of their potential for crop production. Examining component indices for physical, chemical, biological, or nutrient processes (data not presented), rankings in the 0 to $5 \mathrm{~cm}$ (0 to 
Table 2

Overall analysis of variance test (ANOVA) results for measured soil quality indicator data from the 0 to $5 \mathrm{~cm}$ and 5 to $15 \mathrm{~cm}$ depth increments within five midwestern cropland Conservation Effects Assessment Project watersheds.

\begin{tabular}{|c|c|c|c|c|c|c|c|c|c|c|c|}
\hline Factor & $\begin{array}{l}\text { Clay } \\
\left(\mathrm{g} \mathrm{kg}^{-1}\right)\end{array}$ & $\begin{array}{l}\text { Soc } \\
\left(g^{\prime} \mathrm{kg}^{-1}\right)\end{array}$ & $\begin{array}{l}\text { WSA } \\
\left(\mathrm{g} \mathrm{kg}^{-1}\right)\end{array}$ & $\begin{array}{l}\text { MBC } \\
\left(\mu g g^{-1}\right)\end{array}$ & pH & $\begin{array}{l}P \\
\left(\mathrm{mg} \mathrm{kg}^{-1}\right)\end{array}$ & $\begin{array}{l}\mathrm{K} \\
\left(\mathrm{mg} \mathrm{kg}{ }^{-1}\right)\end{array}$ & $\begin{array}{l}\text { BD } \\
\left(\mathrm{g} \mathrm{cm}^{-3}\right)\end{array}$ & $\begin{array}{l}E C \\
\left(d s ~ m^{-1}\right)\end{array}$ & 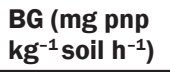 & $\begin{array}{l}\text { PMN } \\
\left(\mathrm{mg} \mathrm{g}^{-1}\right)\end{array}$ \\
\hline \multicolumn{12}{|l|}{0 to $5 \mathrm{~cm}$ depth } \\
\hline Watershed (WS) & $* \star \star$ & NS & $\star * \star$ & $\star * \star$ & $\star * *$ & $\star * *$ & $\star \star *$ & $\star \star \star$ & $* * *$ & $\star \star \star$ & $* \star *$ \\
\hline Manure (M) & NS & NS & $\star * *$ & NS & NS & NS & NS & $* *$ & NS & $* *$ & NS \\
\hline Tillage (T) & $* *$ & NS & NS & NS & * & NS & NS & NS & $* \star *$ & * & NS \\
\hline Crop Rotation (CR) & NS & NS & $* * *$ & $* * *$ & NS & $* * *$ & * & $\star * \star$ & $* *$ & $\star * *$ & $* \star *$ \\
\hline WS (M) & NS & NS & $* * *$ & $\star * *$ & NS & NS & $\star \star$ & NS & $\star * *$ & $\star \star *$ & $\star * \star$ \\
\hline WS $(T)$ & $* *$ & NS & $\star * \star$ & $* * *$ & $\star \star \star$ & $\star$ & NS & $* *$ & * & $\star$ & NS \\
\hline WS (CR) & $* * *$ & NS & $* * *$ & $* * *$ & $* * *$ & $\star * *$ & $* * *$ & * & $* *$ & $* \star *$ & $* * *$ \\
\hline \multicolumn{12}{|l|}{5 to $15 \mathrm{~cm}$ depth } \\
\hline WS & $* * *$ & NS & $* * *$ & NS & $* *$ & $* * *$ & $\star * *$ & $* \star *$ & $* * *$ & NS & $* * *$ \\
\hline $\mathrm{M}$ & NS & NS & NS & NS & NS & NS & NS & $* *$ & NS & NS & NS \\
\hline $\mathrm{T}$ & NS & NS & ** & NS & NS & NS & NS & NS & $* *$ & NS & $* * *$ \\
\hline $\mathrm{CR}$ & NS & NS & $* * *$ & $* * *$ & NS & $\star * *$ & $* *$ & NS & $\star \star \star$ & $\star \star *$ & $* * *$ \\
\hline WS (M) & NS & NS & ** & * & NS & * & $\star *$ & NS & NS & $* *$ & * \\
\hline WS $(T)$ & * & NS & $* *$ & NS & NS & $* * *$ & NS & NS & NS & NS & NS \\
\hline WS (CR) & NS & NS & $* * *$ & NS & $* *$ & $* * *$ & $* * *$ & $* *$ & NS & $\star * *$ & * \\
\hline \multicolumn{12}{|c|}{$\begin{array}{l}\text { Notes: Clay = clay content. } \mathrm{SOC}=\text { soil organic carbon. } \mathrm{WSA}=\text { water stable macroaggregates. } \mathrm{MBC}=\text { microbial biomass carbon. } \mathrm{P}=\text { soil-test phospho- } \\
\text { rus. } \mathrm{K}=\text { soil-test potassium. } \mathrm{BD}=\text { bulk density. } \mathrm{EC}=\text { electrical conductivity. } \mathrm{BG}=\beta \text {-glucosidase. } \mathrm{PMN}=\text { potentially mineralizable nitrogen. }\end{array}$} \\
\hline
\end{tabular}

2 in) increment were biological $<$ physical $<$ chemical $<$ nutrient functions. This presumably reflects the attention given to soil fertility within these agricultural WS. Within the 5 to $15 \mathrm{~cm}$ (2 to 6 in) increment, however, the component SQI rankings (values not presented) were biological $<$ nutrient $=$ physical $<$ chemical fraction. This presumably reflects lower soil-test $\mathrm{P}$ and $\mathrm{K}$ values and potential soil compaction and/or soil $\mathrm{pH}$ problems at the lower sampling depth.

Indicator Response to Manure. Table 2 shows significant difference due to $\mathrm{M}$ application within the past one or two years only for WSA, BD, and BG in the surface samples and for $\mathrm{BD}$ in the 5 to $15 \mathrm{~cm}$ (2 to 6 in) samples. The quantity of WSA was significantly lower in 0 to $5 \mathrm{~cm}$ (0 to 2 in) samples from sites with a history of $\mathrm{M}$ application, but based on metadata comments indicating $\mathrm{M}$ was generally applied to lighter texture soils, the WSA response may have been due to lower clay content.

Although differences were not significant, Mehlich III soil-test $\mathrm{P}$ concentrations in the 0 to $5 \mathrm{~cm}$ (0 to 2 in) samples were more than $30 \%$ higher in samples from fields that had recently received $\mathrm{M}$ applications (table 3 ). In contrast to this assessment, previous SQ samplings within the SF WS (Karlen et al. 2008b) had shown significant manure appli- cation effects within the 0 to $20 \mathrm{~cm}$ (0) to 8 in) plow layer.

Table 4 shows that $M$ application had significant effects on SOC and BD scores (table 5 ) and SQI values (table 3 ) within the 0 to $5 \mathrm{~cm}$ (0 to $2 \mathrm{in}$ ) depth increment and on soil-test $\mathrm{K}$ scores (table 5 ) within the 5 to $15 \mathrm{~cm}$ (2 to 6 in) increment. However, sites receiving $\mathrm{M}$ within the two years of sample collection actually had lower SOC scores and higher $\mathrm{BD}$ scores within the 0 to $5 \mathrm{~cm}$ increment and lower soil-test $\mathrm{K}$ concentrations and $\mathrm{K}$ scores within the 5 to $15 \mathrm{~cm}$ increment (all indicating a lower SQ). The SQI values, although significantly different indicated the soils were functioning at $83 \%$ or $84 \%$ of their inherent potential with or without recent $M$ application.

Indicator Response to Tillage. Table 2 shows highly significant $(p \leq 0.01) \mathrm{T}$ effects on EC values within the 0 to $5 \mathrm{~cm}(0$ to 2 in) increment and significant $(p \leq 0.05)$ EC differences in the 5 to $15 \mathrm{~cm}$ (2 to 6 in) increment. This may have been caused by mixing of residual fertilizer salts or subsurface carbonates during $\mathrm{T}$ operations since measured EC values (table 3) within both depth increments were higher in tilled than nontilled soils. Within the 5 to $15 \mathrm{~cm}$ increment, WSA and PMN values (table 3) were greater in nontilled samples, presumably due to less soil structure disturbance and subsequent oxidation of labile organic materials.

Table 4 shows significant differences for WSA, EC, and BG within the 0 to $5 \mathrm{~cm}$ (0 to 2 in) increment and for $\mathrm{SOC}, \mathrm{BD}$, and $\mathrm{BG}$ within the 5 to $15 \mathrm{~cm}$ ( 2 to 6 in) increment. Electrical conductivity scores were higher in tilled samples from both depth increments, so if $\mathrm{T}$ mixing discussed above occurred, it did not appear to have a negative soil health impact. $\beta$-glucosidase scores for both depth increments were higher for nontilled samples, perhaps reflecting the numerically higher BG level (table 3) within the 0 to 5 $\mathrm{cm}$ increment of nontilled soils. Overall, T had no significant on the average SQI with the 0 to $5 \mathrm{~cm}$ increment functioning at $83 \%$ to $86 \%$ of its potential and the 5 to $15 \mathrm{~cm}$ increment functioning at $70 \%$ to $72 \%$ of its potential (table 3).

Crop Rotation Effects on Soil Quality Indicators. With the exception of SOC, $\mathrm{pH}$, and soil-test $\mathrm{K}$, significant $\mathrm{CR}$ differences were measured within the 0 to $5 \mathrm{~cm}$ ( 0 to 2 in) increment (tables 2 and 3). Similarly, significant CR effects were detected within the 5 to $15 \mathrm{~cm}$ (2 to 6 in) increment for indicators other than SOC, $\mathrm{pH}$, and BD. Continuous corn had the lowest quantity of WSA and highest soil-test $\mathrm{P}$ and $\mathrm{EC}$ values (table 3 ) in the 0 to $5 \mathrm{~cm}$ increment. When normalized through the scoring functions, CR effects on 
Table 3

Mean soil quality indicator and overall soil quality index values for soil samples collected from the o to $5 \mathrm{~cm}$ and 5 to $15 \mathrm{~cm}$ depth increments at sites with different manure, tillage, or crop rotation histories within five midwestern cropland Conservation Effects Assessment Project watersheds.

\begin{tabular}{|c|c|c|c|c|c|c|c|c|c|c|c|}
\hline Factor & $\begin{array}{l}\text { Soc } \\
\left(g_{k g}^{-1}\right)\end{array}$ & $\begin{array}{l}\text { WSA } \\
\left(\mathrm{g} \mathrm{kg}^{-1}\right)\end{array}$ & $\begin{array}{l}\text { MBC } \\
\left(\mu \mathrm{g} \mathrm{g}^{-1}\right)\end{array}$ & pH & $\begin{array}{l}\mathbf{P} \\
\left(\mathrm{mg} \mathrm{kg}^{-1}\right)\end{array}$ & $\begin{array}{l}\mathrm{K} \\
\left(\mathrm{mg} \mathrm{kg}^{-1}\right)\end{array}$ & $\begin{array}{l}\mathrm{BD} \\
\left(\mathrm{g} \mathrm{cm}^{-3}\right)\end{array}$ & $\begin{array}{l}\mathrm{EC} \\
\left(\mathrm{ds} \mathrm{m^{-1 }}\right)\end{array}$ & $\begin{array}{l}\text { BG (Mg pnp } \\
\text { kg }^{-1} \text { soil h}^{-1} \text { ) }\end{array}$ & $\begin{array}{l}\text { PMN } \\
\left(\mathrm{mg} \mathrm{g}^{-1}\right)\end{array}$ & SQI \\
\hline \multicolumn{12}{|l|}{0 to $5 \mathrm{~cm}$} \\
\hline \multicolumn{12}{|l|}{ Watershed } \\
\hline South Fork (IA) & 31 & 439 & 504 & 7.0 & 103 & 303 & 1.20 & 0.27 & 148 & 50 & 0.83 \\
\hline Walnut Creek (IA) & 28 & 542 & 487 & 6.8 & 42 & 231 & 1.44 & 0.31 & 157 & 39 & 0.78 \\
\hline Cedar Creek (IN) & 28 & 440 & 588 & 6.5 & 104 & 611 & 1.07 & 0.28 & 171 & 40 & 0.84 \\
\hline Mark Twain (MO) & 20 & 895 & 556 & 6.8 & 44 & 186 & 1.35 & 0.28 & 205 & 54 & 0.86 \\
\hline $\begin{array}{l}\text { Upper Big Walnut } \\
\text { Creek }(\mathrm{OH})\end{array}$ & 23 & 670 & 581 & 6.2 & 86 & 223 & 1.23 & 0.16 & 191 & 67 & 0.92 \\
\hline $\mathrm{BMSD}_{(0.05)}$ & NS & 41 & 90 & 0.3 & 22 & 63 & 0.06 & 0.04 & 23 & 8 & 0.02 \\
\hline \multicolumn{12}{|l|}{ Manure } \\
\hline Yes & 26 & 486 & 518 & 6.9 & 103 & 312 & 1.27 & 0.27 & 159 & 48 & 0.83 \\
\hline No & 27 & 589 & 541 & 6.7 & 75 & 324 & 1.24 & 0.27 & 172 & 49 & 0.84 \\
\hline $\mathrm{BMSD}_{(0.05)}$ & NS & 22 & NS & NS & NS & NS & 0.03 & NS & 12 & NS & 0.01 \\
\hline \multicolumn{12}{|l|}{ Tillage } \\
\hline Yes & 27 & 536 & 507 & 6.8 & 82 & 310 & 1.26 & 0.28 & 163 & 47 & 0.83 \\
\hline No & 26 & 650 & 609 & 6.6 & 77 & 350 & 1.21 & 0.24 & 186 & 53 & 0.86 \\
\hline $\begin{array}{l}\mathrm{BMSD}_{(0.05)} \\
\text { Crop rotation }\end{array}$ & NS & NS & NS & NS & NS & NS & NS & 0.02 & NS & NS & NS \\
\hline Continuous corn & 31 & 473 & 502 & 6.9 & 91 & 291 & 1.26 & 0.29 & 157 & 45 & 0.82 \\
\hline Corn-soybean & 27 & 518 & 466 & 6.8 & 75 & 288 & 1.26 & 0.24 & 150 & 46 & 0.83 \\
\hline $\begin{array}{l}\text { Corn-soybean- } \\
\text { wheat }\end{array}$ & 22 & 669 & 548 & 6.7 & 85 & 376 & 1.23 & 0.29 & 198 & 50 & 0.86 \\
\hline $\begin{array}{l}\text { Soybean- } \\
\text { soybean-other }\end{array}$ & 22 & 645 & 531 & 6.3 & 74 & 407 & 1.16 & 0.21 & 182 & 55 & 0.89 \\
\hline Forage-based & 28 & 780 & 933 & 6.5 & 47 & 333 & 1.21 & 0.26 & 200 & 68 & 0.89 \\
\hline BMSD $_{(0.05)}$ & NS & 49 & 107 & NS & 26 & NS & 0.07 & 0.04 & 28 & 9 & 0.03 \\
\hline \multicolumn{12}{|l|}{5 to $15 \mathrm{~cm}$} \\
\hline \multicolumn{12}{|l|}{ Watershed } \\
\hline South Fork (IA) & - & - & - & - & - & - & - & - & - & - & - \\
\hline Walnut Creek (IA) & 25 & 623 & 310 & 6.6 & 20 & 115 & 1.44 & 0.27 & 95 & 27 & 0.69 \\
\hline Cedar Creek (IN) & 24 & 526 & 327 & 6.4 & 56 & 305 & 1.36 & 0.18 & 84 & 39 & 0.75 \\
\hline Mark Twain (MO) & 12 & 868 & 203 & 6.6 & 16 & 113 & 1.35 & 0.17 & 57 & 20 & 0.63 \\
\hline $\begin{array}{l}\text { Upper Big Walnut } \\
\text { Creek }(\mathrm{OH})\end{array}$ & 17 & 650 & 284 & 6.1 & 38 & 133 & 1.28 & 0.11 & 72 & 36 & 0.80 \\
\hline $\mathrm{BMSD}_{(0.05)}$ & NS & 49 & NS & 0.3 & 9 & 41 & 0.06 & 0.04 & NS & 5 & 0.03 \\
\hline \multicolumn{12}{|l|}{ Manure } \\
\hline Yes & 17 & 668 & 326 & 6.4 & 20 & 142 & 1.43 & 0.18 & 66 & 29 & 0.69 \\
\hline No & 19 & 705 & 276 & 6.5 & 34 & 177 & 1.36 & 0.19 & 77 & 30 & 0.71 \\
\hline $\mathrm{BMSD}_{(0.05)}$ & NS & NS & NS & NS & NS & NS & 0.06 & NS & NS & NS & NS \\
\hline \multicolumn{12}{|l|}{ Tillage } \\
\hline Yes & 18 & 659 & 267 & 6.5 & 28 & 166 & 1.38 & 0.20 & 77 & 27 & 0.70 \\
\hline No & 20 & 685 & 296 & 6.4 & 39 & 187 & 1.34 & 0.17 & 75 & 34 & 0.72 \\
\hline $\begin{array}{l}\text { BMSD }_{(0.05)} \\
\text { Crop rotation }\end{array}$ & NS & 26 & NS & NS & NS & NS & NS & 0.02 & NS & 3 & NS \\
\hline Continuous corn & 26 & 625 & 324 & 6.6 & 24 & 121 & 1.39 & 0.29 & 102 & 26 & 0.71 \\
\hline Corn-soybean & 22 & 643 & 245 & 6.4 & 30 & 153 & 1.38 & 0.16 & 72 & 30 & 0.70 \\
\hline $\begin{array}{l}\text { Corn-soybean- } \\
\text { wheat }\end{array}$ & 16 & 688 & 243 & 6.6 & 40 & 207 & 1.35 & 0.18 & 70 & 30 & 0.70 \\
\hline $\begin{array}{l}\text { Soybean- } \\
\text { soybean-other }\end{array}$ & 15 & 655 & 261 & 6.1 & 38 & 195 & 1.34 & 0.13 & 65 & 32 & 0.74 \\
\hline Forage-based & 19 & 747 & 424 & 6.4 & 24 & 175 & 1.33 & 0.16 & 80 & 38 & 0.73 \\
\hline $\mathrm{BMSD}_{(0.05)}$ & NS & 65 & 77 & NS & 11 & 54 & NS & 0.05 & 17 & 7 & 0.04 \\
\hline
\end{tabular}

Notes: SOC $=$ soil organic carbon. $\mathrm{WSA}=$ Water stable macroaggregates. $\mathrm{MBC}=$ microbial biomass carbon. $\mathrm{P}=$ soil-test phosphorus. $\mathrm{K}=$ soil-test po-

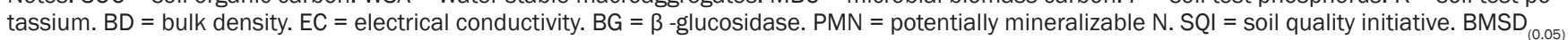
$=$ Bonferroni (Dunn) $t$-Test significance level at $p \leq 0.05$ 
Table 4

Overall analysis of variance test (ANOVA) results for the Soil Management Assessment Framework indicator scores and index value within the o to 5 $\mathrm{cm}$ and 5 to $15 \mathrm{~cm}$ depth increments of five midwestern cropland Conservation Effects Assessment Project watersheds.

\begin{tabular}{|c|c|c|c|c|c|c|c|c|c|c|c|}
\hline Factor & soc & WSA & MBC & pH & $\mathbf{P}$ & $\mathbf{K}$ & BD & EC & BG & PMN & SQI \\
\hline \multicolumn{12}{|l|}{0 to $5 \mathrm{~cm}$ depth } \\
\hline Watershed (WS) & $\star \star \star$ & $\star * *$ & $\star \star \star$ & $* \star *$ & NS & $\star \star \star$ & $\star \star \star$ & $\star \star \star$ & $\star * \star$ & $* *$ & $\star \star *$ \\
\hline Manure (M) & * & NS & NS & NS & NS & NS & $* \star *$ & NS & NS & NS & $* *$ \\
\hline Tillage (T) & NS & $* *$ & NS & NS & NS & NS & NS & $* *$ & * & NS & NS \\
\hline Crop rotation (CR) & $\star * \star$ & $\star *$ & $\star \star *$ & $\star \star *$ & NS & $* \star *$ & $* \star *$ & NS & $\star * \star$ & NS & $* * *$ \\
\hline WS (M) & $* \star$ & * & NS & $\star * *$ & NS & NS & NS & $* \star *$ & $\star \star \star$ & NS & $\star \star$ \\
\hline WS (T) & NS & NS & NS & $* * *$ & NS & * & NS & NS & NS & NS & NS \\
\hline WS (CR) & $* \star *$ & $\star * *$ & * & $\star \star *$ & NS & * & $\star \star \star$ & $\star \star \star$ & $\star \star \star$ & NS & $* * *$ \\
\hline \multicolumn{12}{|l|}{5 to $15 \mathrm{~cm}$ depth } \\
\hline WS & $* * *$ & $\star *$ & $\star * *$ & $* * *$ & $* * *$ & $* * *$ & $* * *$ & $* * *$ & $* \star *$ & $* * *$ & $* * *$ \\
\hline $\mathrm{M}$ & NS & NS & NS & NS & NS & $* *$ & NS & NS & NS & NS & NS \\
\hline $\mathrm{T}$ & * & NS & NS & NS & NS & NS & * & NS & $* *$ & NS & NS \\
\hline $\mathrm{CR}$ & $* *$ & NS & $\star * *$ & NS & NS & NS & $\star \star \star$ & $\star \star \star$ & $* \star \star$ & NS & $* * *$ \\
\hline WS (M) & NS & NS & $* *$ & $\star * *$ & * & $* \star$ & * & * & NS & NS & NS \\
\hline WS (T) & NS & NS & NS & * & $* *$ & NS & NS & * & NS & NS & $* *$ \\
\hline WS (CR) & NS & $\star \star$ & * & $\star \star$ & $\star \star$ & $\star * \star$ & * & $\star \star \star$ & $\star \star \star$ & NS & $\star \star$ \\
\hline
\end{tabular}

Notes: $\mathrm{SOC}=$ soil organic carbon. WSA $=$ Water stable macroaggregates $\left(\mathrm{g} \mathrm{kg}^{-1}\right) . \mathrm{MBC}=$ Microbial Biomass Carbon $\left(\mu \mathrm{g} \mathrm{g}^{-1}\right)$. $\mathrm{P}=\mathrm{soil-test} \mathrm{phosphorus}$

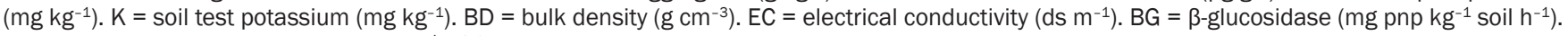
$\mathrm{PMN}=$ potentially mineralizable $\mathrm{N}\left(\mathrm{mg} \mathrm{g}^{-1}\right)$. SQI = soil quality index.

$* p<0.10 * * p<0.05 * * * p<0.01$

soil-test P, EC, and PMN within the 0 to 5 $\mathrm{cm}$ increment were not significantly different (table 4), but SOC and soil-test $\mathrm{K}$ differences were significant at $p \leq 0.01$.

The overall ANOVA (table 4) showed that CR significantly affected SQI ratings, but all five systems were functioning at between $82 \%$ and $89 \%$ or from $70 \%$ to $74 \%$ of their potential within the 0 to $5 \mathrm{~cm}$ (0 to 2 in) or 5 to $15 \mathrm{~cm}$ ( 2 to $6 \mathrm{in}$ ) increment, respectively (table 3). Continuous corn had one of the lower SQI ratings within both sampling depths, while forage-based rotations were among the highest. This is consistent with previous midwestern SQ studies (Karlen et al. 2008b) and agrees with similar cropping system and manure application studies on other claypan soils in Missouri (Veum et al. 2014). They reported that perennial vegetation (i.e., native prairie, restored prairie or timothy [Phleum pretense]) sites had the highest SMAF indices (0.94 to 0.98), followed by no-till and conventionally tilled crop production treatments. Within the five cropland CEAP WS evaluated for this study, soils from the 0 to $5 \mathrm{~cm}$ ( 0 to $2 \mathrm{in}$ ) depth were functioning at $89 \%$ of their potential.

\section{Summary and Conclusions}

The objectives for this study were to (1) evaluate several SQ indicators within five ARS experimental watersheds and (2) determine if those indicators were affected by WS location, $\mathrm{M}$ application within the past year, $\mathrm{T}$ practice, or CR. Detecting significant SOC changes was difficult because of high variability among the sampling sites, but using SMAF scoring curves to normalize the data and help interpret the measurements did result in statistically significant differences due to WS location and CR. Several other SQ indicators showed significant WS differences. Only a few of the indicators showed significant $\mathrm{M}$ orT effects, presumably because the varied sampling designs resulted in substantial inequality in the number of samples being compared in those groups. Among the five CR treatments, continuous corn generally had lower SQI values than forage-based systems. Finally, although the ARS CEAP WS provide a moderately controlled example, we conclude that watershed-scale monitoring of SQ is feasible and suggest its assessment can be used to monitor soil health and/or conservation practices. The next step for long-term soil quality/health assessments within these and similar midwestern watersheds will be to use this initial sampling as a baseline for comparisons with future assessments conducted every three, five, or even ten years. This could be implemented through existing NRCS conservation programs by working with soil-testing and crop consulting groups to monitor effectiveness of these and other conservation programs within cropland watersheds such as the five sampled for this study.

\section{Disclaimer}

Mention of trade names or commercial products in this publication is solely for the purpose of providing specific information and does not imply recommendation or endorsement by the USDA.

\section{References}

Alexander, M. 1971. Agriculture's responsibility in establishing soil quality criteria. pp. 66-71. In Environmental Improvement - Agriculture's Challenge in the Seventies. Washington, DC: National Academy of Sciences.

Andrews, S.S., D.L. Karlen, and J.P. Mitchell. 2002a. A comparison of soil quality indexing methods for vegetable production systems in northern California. Agricultural Ecosystems and the Environment 90:25-45. Andrews, S.S., J.P. Mitchell, R. Mancinelli, D.L. Karlen, T.K Hartz, W.R. Horwath, G.S. Pettygrove, K.M. Scow, and D.S. Munk. 2002b. On-farm assessment of soil quality in California's Central Valley. Agronomy Journal 94:12-23.

Andrews, S.S., D.L. Karlen, and C.A. Cambardella. 2004. The soil management assessment framework: A quantitative evaluation using case studies. Soil Science Society of America Journal 68:1945-1962.

Beeson, P.C., P.C. Doraiswamy, A.M. Sadeghi, M. Di Luzio, M.D. Tomer, J.G. Arnold, and C.S.T. Daughtry. 2011. Treatments of precipitation inputs to hydrologic models. Transactions American Society of Agricultural and Biological Engineers 54(6):2011-2020.

Brookes, P.C., A. Landman, G. Pruden, and D.S. Jenkinson. 1985. Chloroform fumigation and the release of soil 
Table 5

Mean Soil Management Assessment Framework scores for soil quality indicators measured using samples from the o to $5 \mathrm{~cm}$ and 5 to $15 \mathrm{~cm}$ depth increments at sites with different manure, tillage, or crop rotation histories within five midwestern cropland Conservation Effects Assessment Project watersheds.

\begin{tabular}{|c|c|c|c|c|c|c|c|c|c|c|}
\hline Factor & $\begin{array}{l}\text { SOC } \\
\text { score }\end{array}$ & $\begin{array}{l}\text { WSA } \\
\text { score }\end{array}$ & $\begin{array}{l}\text { MBC } \\
\text { score }\end{array}$ & $\begin{array}{l}\text { pH } \\
\text { score }\end{array}$ & $\begin{array}{l}\text { P } \\
\text { score }\end{array}$ & $\begin{array}{l}\text { K } \\
\text { score }\end{array}$ & $\begin{array}{l}\text { BD } \\
\text { score }\end{array}$ & $\begin{array}{l}\text { EC } \\
\text { score }\end{array}$ & $\begin{array}{l}\text { BG } \\
\text { score }\end{array}$ & $\begin{array}{l}\text { PMN } \\
\text { score }\end{array}$ \\
\hline \multicolumn{11}{|l|}{0 to $5 \mathrm{~cm}$} \\
\hline \multicolumn{11}{|l|}{ Watershed } \\
\hline Walnut Creek (IA) & 0.62 & 0.95 & 0.84 & 0.88 & 0.94 & 0.94 & 0.53 & 0.98 & 0.19 & 0.97 \\
\hline Cedar Creek (IN) & 0.61 & 0.85 & 0.94 & 0.88 & 0.96 & 1.00 & 0.95 & 0.99 & 0.26 & 1.00 \\
\hline $\mathrm{BMSD}_{(0.05)}$ & 0.09 & 0.04 & 0.05 & 0.04 & NS & 0.02 & 0.06 & 0.04 & 0.06 & 0.05 \\
\hline \multicolumn{11}{|l|}{ Manure } \\
\hline Yes & 0.65 & 0.92 & 0.93 & 0.88 & 0.87 & 0.96 & 0.87 & 0.96 & 0.26 & 0.98 \\
\hline No & 0.70 & 0.94 & 0.93 & 0.88 & 0.95 & 0.95 & 0.76 & 0.96 & 0.41 & 0.98 \\
\hline $\mathrm{BMSD}_{(0.05)}$ & 0.04 & NS & NS & NS & NS & NS & 0.03 & NS & NS & NS \\
\hline $\mathrm{BMSD}_{(0.05)}$ & NS & 0.02 & NS & NS & NS & NS & NS & 0.02 & 0.03 & NS \\
\hline \multicolumn{11}{|l|}{ Crop rotation } \\
\hline Continuous corn & 0.65 & 0.93 & 0.90 & 0.88 & 0.90 & 0.95 & 0.83 & 0.97 & 0.20 & 0.98 \\
\hline Corn-soybean & 0.66 & 0.93 & 0.90 & 0.88 & 0.94 & 0.95 & 0.80 & 0.95 & 0.30 & 0.96 \\
\hline Corn-soybean-wheat & 0.69 & 0.92 & 0.96 & 0.84 & 0.96 & 0.97 & 0.69 & 0.98 & 0.61 & 0.95 \\
\hline Soybean-soybean-other & 0.86 & 0.98 & 0.98 & 0.90 & 0.95 & 0.92 & 0.81 & 0.91 & 0.61 & 1.00 \\
\hline Forage-based & 0.79 & 0.99 & 0.98 & 0.96 & 0.97 & 0.96 & 0.79 & 0.94 & 0.54 & 1.00 \\
\hline $\mathrm{BMSD}_{(0.05)}$ & 0.10 & 0.04 & 0.06 & 0.05 & NS & 0.03 & 0.07 & NS & 0.07 & NS \\
\hline
\end{tabular}

5 to $15 \mathrm{~cm}$

Watershed

South Fork (IA)

Walnut Creek (IA)

Cedar Creek (IN)

Mark Twain (MO)

Upper Big Walnut Creek (OH)

BMSD $_{(0.05)}$

Manure

Yes

No

BMSD $_{(0.05)}$

Tillage

Yes

No

BMSD $_{(0.05)}$

Crop rotation

Continuous corn

Corn-soybean

Corn-soybean-wheat

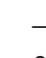

Soybean-soybean-other

Forage-based

BMSD $_{(0.05)}$

$\begin{array}{llll}- & - & - & - \\ 0.52 & 0.98 & 0.55 & 0.90 \\ 0.46 & 0.92 & 0.70 & 0.88 \\ 0.30 & 1.00 & 0.48 & 0.85 \\ 0.83 & 1.00 & 0.98 & 0.94 \\ 0.08 & 0.03 & 0.10 & 0.04 \\ & & & \\ 0.42 & 0.99 & 0.81 & 0.88 \\ 0.49 & 0.97 & 0.64 & 0.88 \\ \text { NS } & \text { NS } & \text { NS } & \text { NS } \\ & & & \\ 0.47 & 0.98 & 0.62 & 0.89 \\ 0.51 & 0.97 & 0.68 & 0.88 \\ 0.04 & \text { NS } & \text { NS } & \text { NS } \\ & & & \\ 0.57 & 0.99 & 0.58 & 0.90 \\ 0.48 & 0.98 & 0.58 & 0.89 \\ 0.43 & 0.95 & 0.62 & 0.86 \\ 0.58 & 0.98 & 0.81 & 0.90 \\ 0.49 & 1.00 & 0.85 & 0.93 \\ 0.11 & \text { NS } & 0.13 & \text { NS }\end{array}$

\begin{tabular}{llllll}
- & - & - & - & - & - \\
0.66 & 0.75 & 0.49 & 0.94 & 0.08 & 0.97 \\
0.94 & 0.95 & 0.63 & 0.90 & 0.08 & 1.00 \\
0.65 & 0.76 & 0.42 & 0.83 & 0.13 & 0.88 \\
0.88 & 0.80 & 0.82 & 0.64 & 0.16 & 0.96 \\
0.09 & 0.05 & 0.07 & 0.06 & 0.04 & 0.07 \\
& & & & & \\
0.67 & 0.74 & 0.48 & 0.89 & 0.10 & 0.90 \\
0.79 & 0.83 & 0.58 & 0.84 & 0.11 & 0.95 \\
NS & 0.05 & NS & NS & NS & NS \\
& & & & & \\
0.76 & 0.82 & 0.54 & 0.86 & 0.10 & 0.95 \\
0.82 & 0.84 & 0.61 & 0.81 & 0.12 & 0.95 \\
NS & NS & 0.04 & NS & 0.02 & NS \\
& & & & & \\
0.71 & 0.77 & 0.55 & 0.95 & 0.10 & 0.94 \\
0.80 & 0.83 & 0.55 & 0.79 & 0.09 & 0.97 \\
0.79 & 0.86 & 0.55 & 0.87 & 0.12 & 0.94 \\
0.85 & 0.81 & 0.65 & 0.73 & 0.10 & 0.97 \\
0.76 & 0.79 & 0.65 & 0.79 & 0.14 & 0.93 \\
NS & NS & 0.10 & 0.08 & 0.05 & NS \\
\hline
\end{tabular}

Notes: $\mathrm{SOC}=$ soil organic carbon. $\mathrm{WSA}=$ Water stable macroaggregates. $\mathrm{MBC}=$ Microbial Biomass Carbon. $\mathrm{P}=$ soil-test phosphorus. $\mathrm{K}=$ soil test

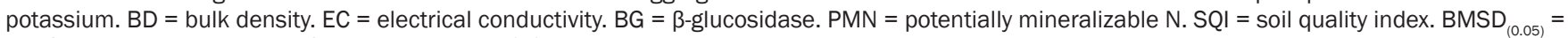
Bonferroni (Dunn) $t$-Test significance level at $p \leq 0.05$ 
nitrogen: A rapid direct extraction method to measure microbial biomass nitrogen in soil. Soil Biology \& Biochemistry 17: 837-842.

CCME (Canadian Council of Ministers of the Environment). 1999. Canadian soil quality guidelines for the protection of environmental and human health: Introduction. In Canadian Environmental Quality Guidelines, 1999, Canadian Council of Ministers of the Environment, Winnipeg.

Drinkwater, L.E., C.A. Cambardella, J.D. Reeder and C.W. Rice. 1996. Potentially mineralizable nitrogen as an indicator of biologically active soil nitrogen. p. 217-229. In Methods for Assessing Soil Quality, eds. J.W. Doran and A.J. Jones. Madison, WI: Soil Science Society of America Inc.

Eivazi, F., and M.A. Tabatabai. 1988. Glucosidases and galactosidases in soils. Soil Biology \& Biochemistry 20:601-606.

Gee, G.W., and D. Or. 2002. Particle-size analysis. p. 255-293. In Methods of Soil Analysis, part 4, physical methods, eds. J.H. Dane and G.C.Topp. Madison, WI: Soil Science Society of America Inc.

Grossman, R.B., and T.G. Reinsch. 2002. Bulk density and linear extensibility. In Methods of Soil Analysis, part 4 Physical methods, eds. J.H. Dane and G.C. Topp, 201 228. Madison, WI: Soil Science Society of America Inc.

Hatfield, J.J., D.B. Jaynes, M.R. Burkart, C.A. Cambardella, T.B. Moorman, J.H. Prueger, and M.A. Smith. 1999. Water quality in Walnut Creek watershed: Setting and farming practices. Journal of Environmental Quality 28:11-24.

Johnson, J.M.F., G.E. Varvel, D.E. Stott, S.L. Osborne, J.M. Novak, D.L. Karlen, J.A. Lamb, and J.M. Baker. 2014. Crop residue mass needed to maintain soil organic carbon levels: Can it be determined? BioEnergy Research http://link.springer.com/article/10.1007/ s12155-013-9402-8.

Karlen, D.L., M.J. Mausbach, J.W. Doran, R.G. Cline, R.F. Harris, and G.E. Schuman. 1997. Soil quality: A concept, definition, and framework for evaluation. Soil Science Society of America Journal 61:4-10.

Karlen, D.L., S.S. Andrews, and J.W. Doran. 2001. Soil quality: Current concepts and applications. Advances in Agronomy 74:1-40.

Karlen, D.L., S.S. Andrews, B.J. Wienhold, and J.W. Doran. 2003. Soil Quality: Humankind's foundation for survival. Journal of Soil and Water Conservation 58(4):171-179.

Karlen, D.L., E.G. Hurley, S.S. Andrews, C.A. Cambardella, D.W. Meek, M.D. Duffy, and A.P. Mallarino. 2006 Crop rotation effects on soil quality at three northern corn/soybean belt locations. Agronomy Journal 98:484-495.

Karlen, D.L. 2008. A new paradigm for natural resources research: The Conservation Effects Assessment Project. Journal of Soil and Water Conservation 63(6):220a, doi:10.2489/jswc.63.6.220A

Karlen, D.L., S.S. Andrews, B.J. Wienhold, and T.M. Zobeck. 2008a. Soil Quality Assessment: Past, Present and Future. Electronic Journal of Integrative Biosciences 6(1):3-14

Karlen, D.L., M.D. Tomer, J. Neppel, and C.A. Cambardella. 2008b. A preliminary watershed scale soil quality assessment in north central Iowa, USA. Soil and Tillage Research 99:291-299.

Kemper W.D., and R.C. Roseneau. 1986. Aggregate stability and size distribution. In Methods of Soil Analysis, part 1 , Physical and mineralogical methods, eds. A. Klute 425442. Madison, WI: Soil Science Society of America Inc.
King, K.W., P.C. Smiley Jr., B.J. Baker, and N.R. Fausey. 2008. Validation of paired watersheds for assessing conservation practices in the Upper Big Walnut Creek watershed, Ohio. Journal of Soil and Water Conservation 63(6):380-395, doi:10.2489/jswc.63.6.380

Lerch, R.N., E.J. Sadler, N.R. Kitchen, K.A. Sudduth, R.J Kremer, D.B. Myers, C. Baffaut, S.H. Anderson, and C.-H. Lin. 2008. Overview of the Mark Twain Lake/ Salt River Basin conservation effects assessment project. Journal of Soil and Water Conservation 63(6):345-359, doi:10.2489/jswc.63.6.345.

Mehlich, A. 1984. Mehlich 3 soil test extractant: A modification of Mehlich 2 extractant. Communications in Soil Science \& Plant Analysis 15:1409-1416.

NRC (National Research Council). 1989. Alternative agriculture. Washington, DC: National Academy Press.

NRC. 1993. Soil and water quality: An agenda for agriculture. Washington, DC: National Academy of Sciences, National Academy Press.

Pesek, J. 1994. Historical perspective. In Sustainable Agriculture Systems, eds. J.L. Hatfield and D.L. Karlen, 1-19. Boca Raton, FL: CRC Press.

Richardson, C.W., D.A. Bucks, and E.J. Sadler. 2008. The conservation efects assessment project benchmark watersheds: Synthesis of preliminary findings. Journal of Soil and Water Conservation 63(6):590-604 doi:10.2489/jswc.63.6.590.

Sherrod, L.A., G. Dunn, G.A. Peterson and R.L. Kolberg. 2002. Inorganic carbon analysis by modified pressurecalcimeter method. Soil Science Society of America Journal.66:299-305

Smith, D.R., S.J. Livingston, B.W. Zuercher, M.Larose, G.C. Heathman, and C. Huang. 2008. Nutrient losse from row crop agriculture in Indiana. Journal of Soil and Water Conservation 63(6):396-409, doi:10.2489/ jswc.63.6.396.

Stott, D.E., S.S. Andrews, M.A. Liebig, B.J. Wienhold, and D.L. Karlen. 2010. Evaluation of $\beta$-glucosidase activity as a soil quality indicator for the Soil Management Assessment Framework (SMAF). Soil Science Society of America Journal 74:107-119.

Stott, D.E., C.A. Cambardella, R. Wolf, M.D.Tomer, and D.L. Karlen. 2011. A Soil quality assessment within the Iowa River south fork watershed. Soil Science Society of America Journal 75:2271-2282.

Stott, D.E., D.L. Karlen, C.A. Cambardella, and R.D. Harmel. 2013. A soil quality and metabolic activity assessment after fifty-seven years of agricultural management. Soil Science Society of America Journal 77: 903-913

Tomer M.D., T.B. Moorman, and C.G. Rossi. 2008 Assessment of the Iowa River's South Fork watershed: Part 1. Water quality. Journal of Soil and Water Conservation 63:360-370, doi:10.2489/jswc.63.6.360.

USDA NRCS (Natural Resource Conservation Service). 2003. Interpreting the Soil Conditioning Index: A tool for measuring soil organic matter trends. http:// www.nrcs.usda.gov/Internet/FSE_DOCUMENTS/ nrcs143_019219.pdf

Vance, E.D., P.C. Brookes, and D.S. Jenkinson. 1987 Microbial biomass measurements in forest soils: Determination of $\mathrm{kC}$ values and tests of hypotheses to explain the failure of the chloroform fumigationincubation method in acid soils. Soil Biology \& Biochemistry 19:689-696

Veum, K.S., K.W. Goyne, R.J. Kremer, R.J. Miles, and K.A Sudduth. 2014. Biological indicators of soil quality and soil organic matter characteristics in an agricultural management continuum. Biogeochemistry 117:81-99.

Warkentin, B.P., and H.F. Fletcher. 1977. Soil quality for intensive agriculture. In Proceedings of the International Seminar on Soil Environment and Fertility Management in Intensive Agriculture, 594-598. Tokyo: Society of Science of Soil and Manure, National Institute of Agricultural Science.

Watson, M.E., and J.R. Brown. 1998. $\mathrm{pH}$ and lime requirement. In Recommended Chemical Soil Test Procedures for the North Central Region, eds. J.R. Brown, 13-16. NCR Publ. 221. Missouri Agric. Exp. Stn. Bull. SB1001. http://ncera-13.missouri.edu/pdf/ sb1001_updatedOct2012.pdf.

Whitney, D.A. 1998. Soil salinity. In Recommended Chemical Soil Test Procedures for the North Central Region, eds. J.R. Brown, 59-60. NCR Publ. 221 Missouri Agric. Exp. Stn. Bull. SB1001. http://ncera-13. missouri.edu/pdf/sb1001_updatedOct2012.pdf.

Wienhold B.J., D.L. Karlen, S.S. Andrews, and D.E. Stott. 2009. Protocol for Soil Management Assessment Framework (SMAF) soil indicator scoring curve development. Renewable Agriculture and Food Systems 24:260-266.

Zobeck, T.M., A.D. Halvorson, B. Wienhold, V. AcostaMartinez, and D.L. Karlen. 2008. Comparison of two soil quality indexes to evaluate cropping systems in northern Colorado. Journal of Soil and Water Conservation 63(5):329-338, doi:10.2489/jswc.63.5.329. 